agriTECH, 41 (3) 2021, 238-245

\title{
The Effect of Processing and Cooling Methods on Coleus tuberosus in vitro Starch Digestibility
}

\author{
Jhauharotul Muchlisyiyah*, Tri Dewanti Widyaningsih, Retno Wulansari, Hera Sisca Prasmita \\ Food Science and Technology Department, Agricultural Technology Faculty, Universitas Brawijaya, \\ Jl. Veteran Malang 65145, Indonesia \\ *Corresponding author: Jhauharotul Muchlisyiyah, Email: lisyah@ub.ac.id
}

Submitted: March 29, 2019; Revised: April 15, 2020; May 5, 2020; Acceptance: July 6, 2020

\begin{abstract}
Coleus tuberosus, also known as black potato, is one of the Indonesian local tubers consumed as a carbohydrate substituent. Therefore, this study aimed to examine the effect of processing and cooling methods on the in vitro digestibility of black potato starch. Furthermore, two factors Randomized Block Design with a $2 \times 3$ experimental design was used, which consisted of processing methods (boiling, roasting, and microwave) and cooling at room temperature and $4^{\circ} \mathrm{C}$ for 24 hours with 3 repetitions. Black potato flour was compared with the raw form, by assessing some parameters, namely Resistant Starch (RS), Slowly Digestible Starch (SDS), Rapidly Digestible Starch (RDS), and Glycemic Index (GI). Also, the analysis of total starch, moisture, and color was performed, hence raw black potatoes generally have $10 \%$ resistant starch (\%wb). Different treatments of cooking and cooling had a significant effect $(a=0.05)$ on moisture content, total starch, RS, RDS, SDS, GI, brightness $(L)$, and yellowness (b). Black potatoes subjected to the processing method followed by cooling had lower RDS and increased RS content. Furthermore, refrigeration at $4^{\circ} \mathrm{C}$ for 24 hours reduced the digestibility of black potato starch more than cooling at room temperature. Contrarily, microwaved black potato cooled at room temperature showed a higher digestion rate compared to the raw counterpart. Conclusively, processing followed by cooling reduces the GI and increases the RS content of Coleus tuberosus.
\end{abstract}

Keywords: Coleus tuberosus; cooling; in vitro digestibility; processing; resistant starch

\section{INTRODUCTION}

The prevalence of diabetes patients in Indonesia is $2.1 \%$ of the total population or specifically, up to 6 million people are suffering from the disease (Indonesian Ministry of Health, 2013). Furthermore, their number is estimated to potentially reach 21.3 million in 2030 (Soewanda and Pramono, 2011). This tends to occur in the absence of preventive efforts. The means of preventing diabetes include consumption of carbohydrates a with low glycemic index which often digest without increasing blood sugar drastically (Zhang et al., 2009). Besides, starch digestibility is defined as its ability to be digested in human intestines and the physiological effects created on the blood sugar after consumption. Resistant starch has been proven to be beneficial for people with type 2 diabetes (Kwak et al., 2012), as it is not digested in the small intestine but enters the large intestine and becomes fermented into short-chain fatty acids (Jiang et al., 2020). The urge to raise carbohydrate source consumption with higher RS is needed in society.

Coleus tuberosus locally known as black potato or 'kleci' potatoes is one of the widely available tubers in Indonesia, and the raw form contains $10 \%$ resistant starch (Nugraheni et al., 2014). This plant has been reported to have a good effect on glucose levels, blood lipids, and short-chain fatty acids in mice (Nugraheni 
et al., 2015). Hsum et al. (2010) also reported it to contain maslinic acid possessing anti-cancer activity. In addition, the tuber has compounds that possess antioxidant and anti-cancer properties (Nugraheni et al., 2011). Its capability to decrease blood glucose and lipid levels is much better when boiled or made into flakes (Nugraheni et al., 2015).

Generally, C. tuberosus is potentially prepared into various dishes and usually processed by frying, boiling, roasting, or mixing with vegetables. The varied cooking processes affect its digestibility, such that almost all techniques used promote starch hydrolysis (Singh, et al., 2010). Also, these processes tend to enhance the resistant starch content. According to Inan Eroglu and Buyuktuncer (2017), starch is either boiled, steamed, fried, roasted, microwaved, autoclaved, or baked during cooking, which in combination with a period of cooling leads to higher RS levels' development due to retrogradation. Furthermore, starch retrogradation is usually accompanied by physical changes such as swelling, gelling, pasting, alteration of functional and mechanical properties, including disorganization of starch granule structures and crystalline formation (Matignon and Tecante, 2017).

Coleus Tuberosus is a local commodity that has not been commercialized, while its preparation for consumption only uses simple methods. However, the related foods processed using different methods tend to have different resistant starch levels, because of subsequent changes in structural and chemical composition. The black potato tuber is expected to be used as a functional food or rice substitute, good for people with diabetes and obesity. Therefore, this study was conducted to determine the effect of processing followed by cooling on in vitro digestibility of $C$. tuberosus.

\section{MATERIALS AND METHODS}

\section{Raw Materials}

The plant samples used were obtained from Jaten Village, Jogorogo District, Ngawi Regency, Indonesia, at maximum days of harvesting in the dry season at 2-3 cm diameter.

\section{Chemicals and Enzymes}

The materials used included $25 \% \mathrm{HCl}$ solution, $45 \% \mathrm{NaOH}$ solution, petroleum ether solution (PE), 0.2 $\mathrm{M} \mathrm{HCl}-\mathrm{KCl}$ buffer solution of $\mathrm{pH} 1.5,2 \mathrm{M} \mathrm{KOH}$ solution, pepsin Sigma-Aldrich), pancreatin a-amylase enzyme (Sigma-Aldrich), $300 \mathrm{U} / \mathrm{mL}$ amyloglucosidases (SigmaAldrich), $100 \mathrm{mM}$ sodium maleate buffer solution of $\mathrm{pH}$
6 , and $0.2 \mathrm{M}$ tris maleate buffer solution of $\mathrm{pH}$ 6.9. Also, $1.2 \mathrm{M}$ sodium acetate buffer solution of $\mathrm{pH} 3.8,100$ $\mathrm{mM}$ sodium acetate buffer solution of $\mathrm{pH} 4.5,0.4 \mathrm{M}$ sodium acetate buffer solution of $\mathrm{pH} 4.75$, aquadest, $99 \%, 50 \%$ and $10 \%(\mathrm{v} / \mathrm{v})$ ethanol, as well as Nelson, Arsenomolibdat and DNS reagents were used, with all chemicals being of analytical grade.

\section{Experimental Design}

Two factors Randomized Block Design (RBD) with $2 \times 3$ experimental design was used, which were the preparation methods (boiling, microwave, and roasting) and cooling (room temperature and refrigeration at 4 ${ }^{\circ} \mathrm{C}$ for 24 hours), where each treatment was performed with 3 replications.

\section{Sample Treatment}

\section{Raw C. tuberosus}

Coleus Tuberosus was treated, cooled to room temperature, and refrigerated at $4{ }^{\circ} \mathrm{C}$ for 24 hours. Then, the tuber was washed and stripped to clean the dirt that sticks to the skin followed by mashing into a raw puree.

\section{C. tuberosus flour}

The sample was washed, stripped, and sliced, then dried at $60^{\circ} \mathrm{C}$ for 7 hours with the cabinet drier, followed by grinding using a blender and sieving with 80 mesh sieve. The flour was treated, cooled to room temperature, and refrigerated at $4^{\circ} \mathrm{C}$ for 24 hours.

\section{Boiled C. tuberosus}

Coleus Tuberosus was washed, then boiled for 50 minutes in $100 \mathrm{~mL}$ of water at $100{ }^{\circ} \mathrm{C}$ in a household pan and dried afterward. It was further treated, cooled to room temperature, and refrigerated at $4^{\circ} \mathrm{C}$ for 24 hours, followed by peeling and mashing into a puree.

\section{Roasted C. tuberosus}

The potato tuber was washed and roasted for 30 minutes at $200{ }^{\circ} \mathrm{C}$ in Cosmos CO-9919R household roasting condition, then cooled to room temperature and refrigerated at $4^{\circ} \mathrm{C}$ for 24 hours, after which it was peeled and mashed into a puree.

\section{Microwaved C. tuberosus}

Coleus Tuberosus was washed and microwaved with $30 \mathrm{~V}$ power level for 3 minutes in Samsung M 745 
household microwave settings. This was treated, cooled to room temperature, and refrigerated at $4{ }^{\circ} \mathrm{C}$ for 24 hours, then peeled and mashed.

\section{Moisture Content, Total Starch, and Color Analysis}

Moisture content was determined by using thermogravimetry analysis (AOAC, 2005) and total starch was assessed by acid hydrolysis using the nelson somogy method (AOAC, 1990), while color was analyzed with a color reader (Susanto and Yuwono, 1998).

\section{Starch Digestibility (In Vitro) Analysis (Goñi et al., 1997)}

To carry out the analysis, $50 \mathrm{mg}$ puree samples were put into some test tubes. Next, $10 \mathrm{~mL} \mathrm{HCl}-\mathrm{KCl}$ buffer and $2 \mathrm{~mL}$ pepsin solution (1 $\mathrm{mg}$ pepsin in 10 $\mathrm{mL} \mathrm{HCl}-\mathrm{KCl}$ buffer of $\mathrm{pH} 1.5$ ) were added and vortexed. The mixture was incubated at $40{ }^{\circ} \mathrm{C}$ for 60 minutes and up to $25 \mathrm{~mL}$ tris-maleate buffer of $\mathrm{pH} 6.9$ was added. The $5 \mathrm{~mL}$ tris-maleate buffer containing $2.6 \mathrm{IU}$ a-amylase was added and vortexed, then the mixture was incubated at $37^{\circ} \mathrm{C}$. Every 30, 60, 90, 120, 150, and 180 mins, $0.2 \mathrm{ml}$ of the mixture was collected then heated for 5 mins to inactivate the enzyme present. Into this, $60 \mu$ amyloglucosydases $(300 \mathrm{U} / \mathrm{mL})$ and $2 \mathrm{~mL}$ of $0.4 \mathrm{M}$ sodium acetate buffer with $\mathrm{pH} 4.75$ was added, then mixed thoroughly. The solution was incubated at $60{ }^{\circ} \mathrm{C}$ for $45 \mathrm{mins}$, after which $2 \mathrm{ml}$ dinitrosalycilic acid was added and vortexed, followed by heating for 15 mins and glucose content was later measured with spectrophotometer $\lambda 540 \mathrm{~nm}$.

\section{Rapidly Digestible Starch (RDS) Analysis (Englyst et al., 1992)}

Glucose data from the 30,60, and 90 minutes digestibility in vitro analysis were collected and multiplied with 0.9 (the starch conversion factor).

\section{Slowly Digestible Starch (SDS) Analysis (Englyst et al., 1992)}

Glucose data from 120, 150, and 180 minutes digestibility in vitro analysis were collected and multiplied with 0.9 (the starch conversion factor).

\section{Resistant Starch (RS) Analysis (Englyst et al., 1992)}

Resistant starch was determined as:

$R S=T S-(S D S+R D S)$

\section{Glycemic Index (GI) Analysis (Goñi et al., 1997)}

Each \% starch hydrolysis was measured as:

$\%$ starch hydrolysis $=\frac{\text { glucose concentration every } 30 \text { minutes }}{\text { total starch }} \times 100 \%$

Hydrolysis index (HI) and glycemic index (GI) was calculated as:

$H I=\frac{\text { area under curves }(A U C) \text { sample }}{\text { area under curves }(A U C) \text { white bread }} \times 100 \%$

$G I=39.71+(0.549 \times H I)$

\section{Data Analysis}

Data analysis was performed with ANOVA method using Minitab 17 followed by Duncan's multiple range test $(a=0.05)$ for the treatment factor type of processing and cooling.

\section{RESULTS AND DISCUSSION}

\section{Moisture and Total Starch}

The moisture content of $C$. tuberosus after being treated with six types of cooking and cooling processes $(a=0.05)$ can be seen in Table 1 , which was influenced by the methods used. The lowest water content was discovered in the roasted sample at $200{ }^{\circ} \mathrm{C}$ followed by the one refrigerated (52.95\%). But, the highest was in samples boiled and cooled at room temperature $(72.30 \%)$. Besides, the low humidity of the air in the roaster created a vapor pressure gradient causing water to move from the inside of the material to the surface and which eventually evaporated (Revlisia, 2012). The boiling process caused water to enter the sample because of the vapor pressure gradient (Fitriani, 2008) and cell damage (Amon et al., 2011).

According to Table 1, different processing methods affect total starch $(a=0.05)$. Based on temperature and water activity, thermal processes enhance starch hydrolysis rate by gelatinization (Alsaffar, 2011). Contrarily, Eleazu et al. (2017) and Capriles et al. (2008) said differences in cooking methods did not significantly affect total starch in food ingredients. The highest total starch was obtained by boiling C. tuberosus followed by cooling to room temperature $(86.59 \%)$, and this is possibly due to the complete gelatinization process in boiling with adequate temperature and water availability. When starch granules in the water are exposed to heat, intermolecular and intramolecular hydrogen bonds between their chains are disrupted, allowing granular enlargement and disintegration. This makes starch to be easily hydrolyzed by enzymes, however, its content is lessened in roasters and microwaves. 
Table 1. The moisture content and total starch of $C$. tuberosus after processing and cooling

\begin{tabular}{lll}
\hline Processing and cooling methods of Coleus tuberosus & moisture (\%wb) & total starch (\%db) \\
\hline Raw, cooled at room temperature & $71.29 \pm 2.31$ & $84.64 \pm 5.17$ \\
Raw, refrigerated at $4^{\circ} \mathrm{C}$ for 24 hours & $9.82 \pm 0.70$ & $58.74 \pm 1.73$ \\
Flour, cooled at room temperature & $69.16 \pm 5.43$ & $74.39 \pm 4.70$ \\
Flour, refrigerated at $4^{\circ} \mathrm{C}$ for 24 hours & $10.41 \pm 0.30$ & $61.81 \pm 1.01$ \\
Boiled, cooled at room temperature & $72.30 \pm 4.90^{\mathrm{b}}$ & $86.59 \pm 6.44^{\mathrm{c}}$ \\
Boiled, refrigeration at $4{ }^{\circ} \mathrm{C}$ for 24 hours & $64.96 \pm 0.92^{\mathrm{ab}}$ & $71.57 \pm 2.14^{\mathrm{ab}}$ \\
Roasted, cooled at room temperature & $60.38 \pm 0.88^{\mathrm{ab}}$ & $71.41 \pm 1.87^{\mathrm{ab}}$ \\
Roasted, refrigeration at $4{ }^{\circ} \mathrm{C}$ for 24 hours & $71.50 \pm 2.76^{\mathrm{b}}$ & $75.33 \pm 1.90^{\mathrm{bc}}$ \\
Microwaved, cooled at room temperature & $52.95 \pm 8.78^{\mathrm{a}}$ & $61.32 \pm 3.47^{\mathrm{a}}$ \\
Microwaved, refrigerated at $4{ }^{\circ} \mathrm{C}$ for 24 hours & $55.32 \pm 9.87^{\mathrm{ab}}$ & $63.14 \pm 0.77^{\mathrm{ab}}$ \\
\hline
\end{tabular}

The $a b c=$ values with the small annotation have no significant difference $(a=0.05)$

\section{In vitro Digestibility Analysis}

Coleus Tuberosus digestibility analysis was conducted after cooking and cooling to determine rapidly digestible starch, slowly digestible starch, and resistant starch according to Goñi et al. (1997), using in vitro method (Table 2). The result showed the treatments affected black potato resistant starch levels ( $a=$ 0.05). Based on Table 2, the cooking process followed by cooling extended the resistant starch levels in $C$. tuberosus. Previous study reported type III resistant starch formation in food during the treatment process
(García-Alonso et al., 1999; Rendon-Villalobos et al., 2002; Tovar et al., 2002; Gonzáles-Soto et al., 2006). Resistant starch content in the sample after cooking and cooling was higher than in the raw potato $(38.18 \%)$, except in microwave processing which was cooled at room temperature $(29.24 \%)$. When cooling is carried out after processing, retrogradation occurs to ensure starch structures become more resistant to enzymatic digestion (Chung et al., 2006). The amount of resistant starch in processed foods compared to the raw material depends on the processing method employed (Alsaffar,

Table 2. In vitro digestibility analysis of $\mathrm{C}$. tuberosus after cooking and cooling

\begin{tabular}{lcccc}
\hline $\begin{array}{l}\text { Processing and cooling methods of Coleus } \\
\text { tuberosus }\end{array}$ & $\begin{array}{c}\text { Resistant starch } \\
(\text { RS) }(\% \mathrm{db})\end{array}$ & $\begin{array}{c}\text { Rapidly digestible } \\
\text { starch (RDS) (\%db) }\end{array}$ & $\begin{array}{c}\text { Slowly digestible } \\
\text { starch (SDS) (\%db) }\end{array}$ & Glycemic index \\
\hline Raw, cooled at room temperature & $38.18 \pm 1.90$ & $23.48 \pm 0.82$ & $22.98 \pm 1.22$ & $64.54 \pm 1.07$ \\
Raw, refrigerated at $4{ }^{\circ} \mathrm{C}$ for 24 hours & $41.19 \pm 0.31$ & $16.79 \pm 0.09$ & $16.41 \pm 0.23$ & $59.85 \pm 0.15$ \\
Flour, cooled at room temperature & $43.84 \pm 0.78$ & $7.40 \pm 0.39$ & $7.50 \pm 0.43$ & $51.12 \pm 0.52$ \\
Flour, refrigerated at $4{ }^{\circ} \mathrm{C}$ for 24 hours & $50.37 \pm 0.94$ & $5.65 \pm 0.43$ & $5.79 \pm 0.51$ & $48.11 \pm 0.68$ \\
Boiled, cooled at room temperature & $49.91 \pm 1.20^{\mathrm{d}}$ & $18.46 \pm 0.45^{\mathrm{c}}$ & $18.21 \pm 1.64^{\mathrm{bc}}$ & $58.93 \pm 0.48^{\mathrm{ab}}$ \\
Boiled, refrigerated at $4{ }^{\circ} \mathrm{C}$ for 24 hours & $49.45 \pm 0.56^{\mathrm{d}}$ & $12.79 \pm 0.77^{\mathrm{a}}$ & $13.09 \pm 0.64^{\mathrm{a}}$ & $57.11 \pm 0.56^{\mathrm{a}}$ \\
Roasted, cooled at room temperature & $40.14 \pm 0.71^{\mathrm{c}}$ & $15.50 \pm 0.42^{\mathrm{b}}$ & $15.93 \pm 0.51^{\mathrm{ab}}$ & $59.60 \pm 0.44^{\mathrm{b}}$ \\
Roasted, refrigerated at $4{ }^{\circ} \mathrm{C}$ for 24 hours & $35.01 \pm 0.19^{\mathrm{b}}$ & $12.89 \pm 0.15^{\mathrm{a}}$ & $13.42 \pm 0.06^{\mathrm{a}}$ & $59.17 \pm 0.17^{\mathrm{ab}}$ \\
Microwave, cooled at room temperature & $29.24 \pm 1.76^{\mathrm{a}}$ & $20.98 \pm 0.86^{\mathrm{d}}$ & $21.18 \pm 0.91^{\mathrm{c}}$ & $66.48 \pm 1.24^{\mathrm{c}}$ \\
Microwave, refrigerated at $4{ }^{\circ} \mathrm{C}$ for 24 hours & $36.52 \pm 0.14^{\mathrm{b}}$ & $13.19 \pm 0.06^{\mathrm{r}}$ & $13.43 \pm 0.08^{\mathrm{a}}$ & $58.76 \pm 0.11^{\mathrm{ab}}$ \\
\hline
\end{tabular}

The $a b c=$ values with the same small annotation have no significant difference $(a=0.05)$ 
2011; Englyst et al., 2007). Therefore, the potato sample's resistant starch was reduced after being treated. In general, refrigeration led to higher resistant starch compared to cooling at room temperature. Starch retrogradation increases with longer storage time and constant temperatures as both parameters are its main factors (Fu et al., 2013; Xie et al., 2014).

The treatment of heating followed by cooling has a significant effect on the RDS levels in $C$. tuberosus ( $a=0.05$ ). Foods containing lots of RDS quickly raise blood glucose and insulin levels (Miao et al., 2013). Notably, the highest RDS was detected in the microwave treatment, cooled at room temperature $(20.98 \%)$ where the sample had the lowest resistant starch. According to Patindol et al. (2010), RS and SDS are not collinier, foods containing high levels of RS do not necessarily have high SDS levels, and vice versa. In general, the amount of RDS in C. tuberosus (12.79$20.98 \%$ ) reduced after heating and cooling treatment compared to the initial sample $(23.48 \%)$. Refrigeration led to a lower RDS value in raw $C$. tuberosus compared to room temperature, while the RDS value after treatment is still higher than that of the flour subjected to both cooling methods.

The SDS is a starch that can be digested in the small intestine at a slower rate than RDS. According to Table 2 , the different cooking processes followed by cooling affected the SDS levels in $C$. tuberosus $(a=0.05)$. The microwave treatment with cooling at room temperature had the highest SDS compared to other treatments $(21.18 \%)$, while refrigeration caused the SDS level to be lower than when cooled at room temperature. In addition, some studies stated consuming foods with high levels of SDS stabilizes blood sugar levels in the body (Vinoy et al., 2013; Peronnet et al., 2015).

Table 2 shows the treatments also affected the glycemic index (GI) of $C$. tuberosus $(a=0.05)$. Jenkins (1981) introduced the GI first, by grouping foods based on the physiological effects on blood glucose levels after consumption. Every food entering the body is digested at different speeds, hence leading to various blood glucose levels. The GI value in this study was around 57 to 66, where a different cooking process produced a different glycemic index. The lowest GI value of 57.11 was obtained from black boiled potatoes with 24-hour cooling at $4{ }^{\circ} \mathrm{C}$. But, the highest (66.48) was in microwaved black potatoes at cooling room temperature. Moreover, cooling time affects RS levels in food as the retrogradation of starch increases when the storage time is longer with constant temperatures (Fu et al., 2013; Xie et al., 2014). The higher the RS level, the lower the GI in the foods consumed because resistant starch is unable to be digested, hence glucose levels in the blood are not increased.

The values of RDS, SDS, RS, and GI of potato flour are based on physiological effects of glucose digestibility

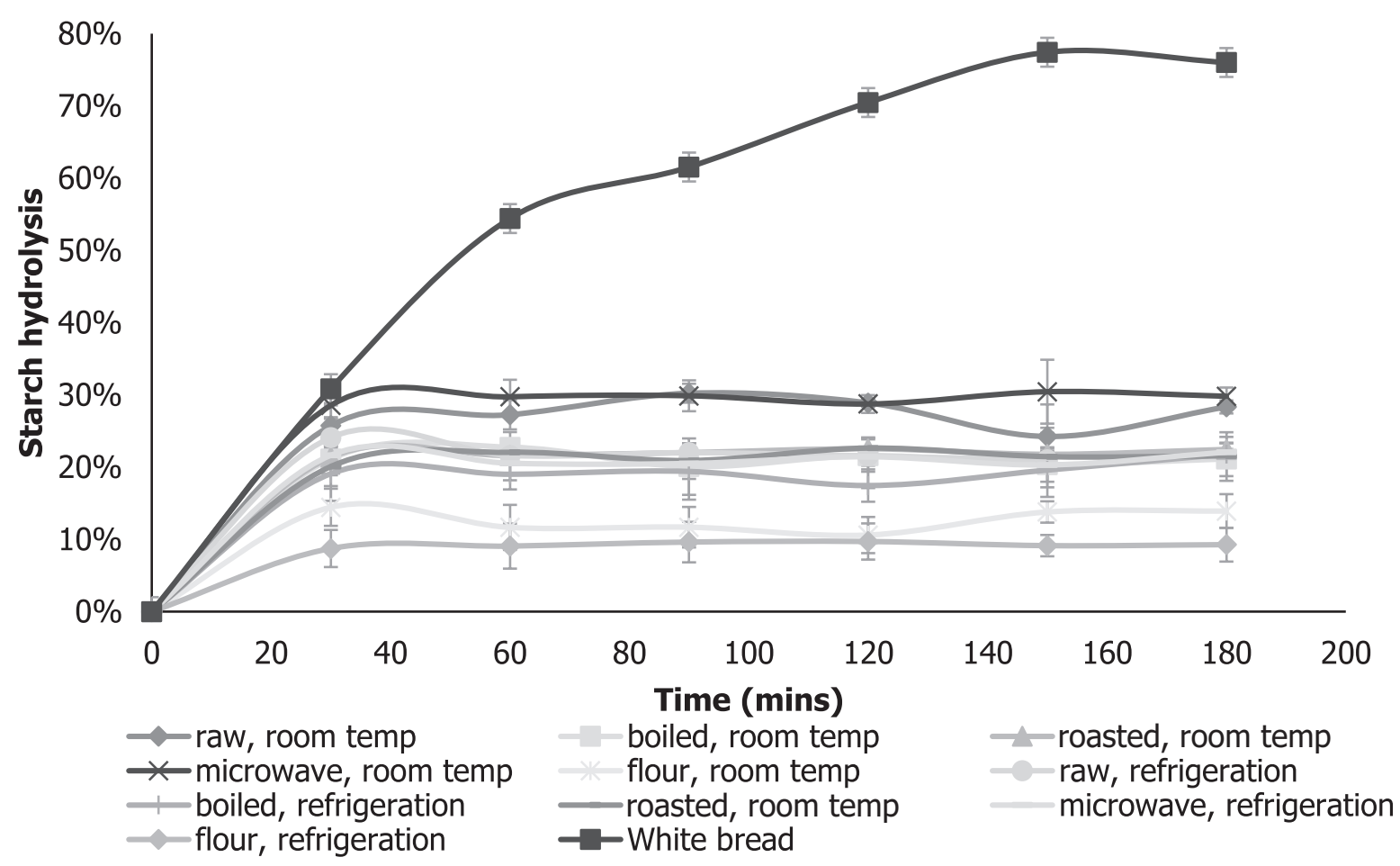

Figure 1. Percentage (\%) hydrolysis of $C$. tuberosus after processing and cooling compared to white bread 
Table 3. Lightness and yellowness of $C$. tuberosus after processing and cooling

\begin{tabular}{|c|c|c|}
\hline Processing and cooling methods of Coleus tuberosus & Lightness (L) & Yellowness $\left(b^{*}\right)$ \\
\hline Raw, cooled at room temperature & $72.7 \pm 0.66$ & $29.63 \pm 0.74$ \\
\hline Raw, refrigerated at $4^{\circ} \mathrm{C}$ for 24 hours & $78.5 \pm 0.97$ & $18.87 \pm 0.26$ \\
\hline Flour, cooled at room temperature & $71.1 \pm 1.34$ & $30.13 \pm 0.93$ \\
\hline Flour, refrigerated at $4^{\circ} \mathrm{C}$ for 24 hours & $79.7 \pm 0.14$ & $18.37 \pm 0.12$ \\
\hline Boiled, cooled at room temperature & $62.2 \pm 1.69 a b$ & $14.30 \pm 0.86 a b$ \\
\hline Boiled, refrigeration at $4^{\circ} \mathrm{C}$ for 24 hours & $63.0 \pm 2.79 a b$ & $11.40 \pm 0.78^{a}$ \\
\hline Roasted, cooled at room temperature & $69.4 \pm 1.31 \mathrm{bc}$ & $19.57 \pm 2.18 \mathrm{ab}$ \\
\hline Roasted, refrigeration at $4^{\circ} \mathrm{C}$ for 24 hours & $62.7 \pm 0.97 \mathrm{ab}$ & $20.67 \pm 3.56^{b}$ \\
\hline Microwave, cooled at room temperature & $60.4 \pm 2.92$ a & $19.43 \pm 3.29 a b$ \\
\hline Microwave, refrigeration at $4^{\circ} \mathrm{C}$ for 24 hours & $71.6 \pm 3.06^{c}$ & $19.43 \pm 2.55 a b$ \\
\hline
\end{tabular}

The $a b c=$ values with the same small annotation have no significant difference $(a=0.05)$

following the in vitro method (Goñi, 1997). In general, foods containing high GI raise blood glucose levels quickly, and those with low IG levels raise the glucose slowly (Atkinson et al., 2008; Rimbawa and Siagian, 2004; Haree-Brun et al., 2008). The hydrolysis level of each treatment was plotted as a sample area under the curve (AUC) compared to the standard AUC food reference for white bread. Percentage starch hydrolysis per 30 minutes sample can be seen in Figure 1 which shows that the rate was lower in the $C$. tuberosus subjected to processing and cooling compared to white bread. The increase in hydrolysis occurred in the initial 30 minutes, but it tended to be more stable afterward.

\section{Color Analysis}

According to Table 3, the six treatment factors of cooking processes followed by cooling affected the brightness and yellowness value $(a=0.05)$, but had no effect on the redness level (data not shown). The lowest brightness value (60.4) was in the $C$. tuberosus roasted for 24 hours with cooling at $4{ }^{\circ} \mathrm{C}$. This was possibly caused by the $200^{\circ} \mathrm{C}$ temperature used for the roaster. However, the highest brightness value (69.4) was in the microwaved sample with cooling at room temperature. The lowest yellowness value (11.4) was obtained from roasted $C$. tuberosus with cooling at room temperature, while the highest (20.7) was in the boiled sample with 24-hour cooling at $4{ }^{\circ} \mathrm{C}$. Generally, the processing decreases brightness and yellowness that are caused by the browning reaction due to polyphenol dehydrogenation (Le Bourvelec et al., 2004).

\section{CONCLUSION}

In summary, this study showed food processing and cooling affect the digestibility of a food ingredient. The heating process with cooling increases RS and SDS, but reduces GI and RDS levels in C. tuberosus. Furthermore, the lowest digestibility was achieved through boiling followed by refrigeration and the highest was through microwaving followed by cooling at room temperature. Generally, the cooling process with refrigeration has a greater effect in lowering starch digestibility than cooling at room temperature. Further analysis is recommended to be carried out on changes in starch structure due to $C$. tuberosus processing.

\section{CONFLICT OF INTEREST}

The authors declare that there is no conflict of interest.

\section{REFERENCES}

Alsaffar, A. A. (2011). Effect of food processing on the resistant starch content of cereals and cereal products - a review. International Journal of Food Science \& Technology, 46(3), 455-462. https://doi.org/10.1111/ j.1365-2621.2010.02529.x

Amon, A. S., Soro, R. Y., Assemand, E. F., Dué, E. A., \& Kouamé, L. P. (2011). Effect of boiling time on chemical composition and physico-functional properties of flours from taro (Colocasia esculenta cv 
fouê) corm grown in Côte d'Ivoire. Journal of Food Science and Technology, 51(5), 855-864.https://doi. org/10.1007/s13197-011-0578-7

AOAC (Association of Official Analitical Chemist). (2005). Official methods of analysis. $18^{\text {th }}$ edition. Gaithersburg (US): AOAC International

AOAC (Association of Official Analitical Chemist). (2002). Official methods of analysis. $17^{\text {th }}$ edition. Marylan (US): AOAC International

Atkinson, F. S., Foster-Powell, K., \& Brand-Miller, J. C. (2008). International Tables of Glycemic Index and Glycemic Load Values: 2008. Diabetes Care, 31(12), 2281-2283. https://doi.org/10.2337/dc08-1239

Capriles, V. D., Coelho, K. D., Guerra-Matias, A. C., \& Arêas, J. A. G. (2008). Effects of processing methods on amaranth starch digestibility and predicted glycemic index. Journal of Food Science, 73(7), H160-H164. https://doi.org/10.1111/j.1750-3841.2008.00869.x

Eleazu, C. O., Eleazu, K. C., Iroaganachi, M. A., \& Kalu, W. (2017). Starch digestibility and predicted glycemic indices of raw and processed forms of hausa potato (Solenostemon rotundifolius poir). Journal of Food Biochemistry, 41(3), e12355. https://doi.org/10.1111/ jfbc. 12355

Englyst, K. N., Liu, S., \& Englyst, H. N. (2007). Nutritional characterization and measurement of dietary carbohydrates. European Journal of Clinical Nutrition, 61(S1), S19-S39. https://doi.org/:10.1038/ sj.ejcn.1602937

Fitriani, S. (2008). Pengaruh suhu dan lama waktu pengeringan terhadap beberapa mutu manisan belimbing wuluh (Averrhoa blimbing L.) kering. Jurnal Teknologi Pangan, 7:32-37. https://ejournal.unri.ac.id/index.php/JSG/ article/view/1100

Fu, Z., Wang, L., Li, D., Zhou, Y., \& Adhikari, B. (2013). The effect of partial gelatinization of corn starch on its retrogradation. Carbohydrate Polymers, 97(2), 512-517. https://doi.org/10.1016/j.carbpol.2013.04.089

García-Alonso, A., Saura-Calixto, F., \& Delcour, J. A. (1998). Influence of botanical source and processing on formation of resistant starch type III. Cereal Chemistry Journal, 75(6), 802-804. https://doi.org/10.1094/ cchem.1998.75.6.802

Goñi, I., García-Alonso, A., \& Saura-Calixto, F. (1997). A starch hydrolysis procedure to estimate glycemic index. Nutrition Research, 17(3), 427-437.https://doi. org/10.1016/s0271-5317(97)00010-9

González-Soto, R. A., Sánchez-Hernández, L., Solorza-Feria, J., Núñez-Santiago, C., Flores-Huicochea, E., \& BelloPérez, L. A. (2006). Resistant starch production from non-conventional starch sources by extrusion. Food Science and Technology International, 12(1), 5-11. https://doi.org/10.1177/1082013206060735

Hare-Bruun, H., Nielsen, B. M., Grau, K., Oxlund, A. L., \& Heitmann, B. L. (2008). Should glycemic index and glycemic load be considered in dietary recommendations? Nutrition Reviews, 66(10), 569-590.https://doi. org/10.1111/j.1753-4887.2008.00108.x

Hsum, Y., Yew, W., Hong, P., Soo, K., Hoon, L., Chieng, Y., \& Mooi, L. (2010). Cancer chemopreventive activity of maslinic acid: suppression of COX-2 expression and inhibition of NF-KB and AP-1 activation in raji cells. Planta Medica, 77(02), 152-157. https://doi. org/10.1055/s-0030-1250203

Inan Eroglu, E., \& Buyuktuncer, Z. (2017). The effect of varıous cookıng methods on resistant starch content of foods. Nutrition \& Food Science, 47(4). doi:10.1108/nfs10-2016-0154

Indonesian Ministry of Health. (2013). Riset Kesehatan Dasar. Jakarta: Indonesian Ministry of Health

Jenkins, D. J., Wolever, T. M., Taylor, R. H., Barker, H., Fielden, H., Baldwin, J. M., Bowling, A. C., Newman, H. C., Jenkins, A. L., \& Goff, D. V. (1981). Glycemic index of foods: a physiological basis for carbohydrate exchange. The American Journal of Clinical Nutrition, 34(3), 362366. https://doi.org/10.1093/ajcn/34.3.362

Jiang, F., Du, C., Jiang, W., Wang, L., \& Du, S. (2020). The preparation, formation, fermentability, and applications of resistant starch. International Journal of Biological Macromolecules, 150, 1155-1161. doi:10.1016/j. ijbiomac.2019.10.124

Kwak, J. H., Paik, J. K., Kim, H. I., Kim, O. Y., Shin, D. Y., Kim, H.-J., Lee, J. H., \& Lee, J. H. (2012). Dietary treatment with rice containing resistant starch improves markers of endothelial function with reduction of postprandial blood glucose and oxidative stress in patients with prediabetes or newly diagnosed type 2 diabetes. Atherosclerosis, 224(2), 457-464. https://doi. org/10.1016/j.atherosclerosis.2012.08.003

Le Bourvellec, C., Le Quéré,, J.-M., Sanoner, P., Drilleau, J.F., \& Guyot, S. (2004). Inhibition of apple polyphenol oxidase activity by procyanidins and polyphenol oxidation products. Journal of Agricultural and Food Chemistry, 52(1), 122-130. https://doi.org/10.1021/jf034461q

Matignon, A., \& Tecante, A. (2017). Starch retrogradation: From starch components to cereal products. Food Hydrocolloids, 68, 43-52. doi:10.1016/j. foodhyd.2016.10.032

Miao, M., Jiang, B., Cui, S. W., Zhang, T., \& Jin, Z. (2013). Slowly digestible starch-a review. Critical Reviews in 
Food Science and Nutrition, 55(12), 1642-1657. https:// doi.org/10.1080/10408398.2012.704434

Nugraheni, M., Santoso, U., \& Wuryastuti, H. (2011). Potential of Coleus tuberosus as an antioxidant and cancer chemoprevention agent. International Food Research Journal, 18(4). https://doi.org/10.5897/jmpr11.122

Nugraheni, M., Santoso, U., \& Windarwati, W. (2014). Effect of consumption of Coleus tuberosus on the lipid profile of alloxan-induced diabetic rats. Advance Journal of Food Science and Technology, 6(2), 159-166. https:// doi.org/10.19026/ajfst.6.3

Nugraheni, M., Hamidah, S., \& Windarwati, W. (2015). Effect of Coleus tuberosus flour high resistant starch consumption in glucose, lipid, digest and short chain fatty acid profile in normal rats. Advance Journal of Food Science and Technology, 8(12), 844-852. https://doi. org/10.19026/ajfst.8.2718

Patindol, J. A., Guraya, H. S., Champagne, E. T., \& McClung, A. M. (2010). Nutritionally important starch fractions of rice cultivars grown in Southern United States. Journal of Food Science, 75(5). https://doi.org/10.1111/j.17503841.2010.01627.x

Péronnet, F., Meynier, A., Sauvinet, V., Normand, S., Bourdon, E., Mignault, D., St-Pierre, D. H., Laville, M., RabasaLhoret, R. \& Vinoy, S. (2015). Plasma glucose kinetics and response of insulin and GIP following a cereal breakfast in female subjects: effect of starch digestibility. European Journal of Clinical Nutrition, 69(6), 740-745. https://doi.org/10.1038/ejcn.2015.50

Rendon-Villalobos, R., Bello-Pérez, L. A., Osorio-Díaz, P., Tovar, J., \& Paredes-López, O. (2002). Effect of storage time on in vitro digestibility and resistant starch content of nixtamal, masa, and tortilla. Cereal Chemistry Journal, 79(3), 340-344. https://doi.org/10.1094/ cchem.2002.79.3.340

Revsilia, R. (2012). Evaluasi Kandungan Nutrien Panicum maximum, Brachiaria decumbens dan Pueraria thunbergiana Melalui Metode Pengeringan yang Berbeda. Institut Pertanian Bogor. Bogor

Rimbawan \& Siagian, A. (2004). Indeks Glikemik Pangan. Penebar Swadaya. Jakarta

Hare-Bruun, H., Nielsen, B. M., Grau, K., Oxlund, A. L., \& Heitmann, B. L. (2008). Should glycemic index and glycemic load be considered in dietary recommendations? Nutrition Reviews, 66(10), 569-590. https://doi. org/10.1111/j.1753-4887.2008.00108.x

Singh, J., Dartois, A., \& Kaur, L. (2010). Starch digestibility in food matrix: a review. Trends in Food Science \& Technology, 21(4), 168-180. doi:10.1016/j. tifs.2009.12.001

Soewondo, P., \& Pramono, L. A. (2011). Prevalence, characteristics, and predictors of pre-diabetes in Indonesia. Medical Journal of Indonesia, 283. https:// doi.org/10.13181/mji.v20i4.465

Tovar, J., Melito, C., Herrera, E., Rascón, A., \& Pérez, E. (2002). Resistant starch formation does not parallel syneresis tendency in different starch gels. Food Chemistry, 76(4), 455-459. https://doi.org/10.1016/ s0308-8146(01)00306-5

Vinoy, S., Normand, S., Meynier, A., Sothier, M., LouchePelissier, C., Peyrat, J., Maitrepierre, C., Nazare, J. A., Brand-Miller, J., \& Laville, M. (2013). Cereal processing influences postprandial glucose metabolism as well as the GI effect. Journal of the American College of Nutrition, 32(2), 79-91. https://doi.org/10.1080/07315 724.2013.789336

Weickert, M. O., \& Pfeiffer, A. F. H. (2008). Metabolic effects of dietary fiber consumption and prevention of diabetes. The Journal of Nutrition, 138(3), 439-442. https://doi. org/10.1093/jn/138.3.439

Xie, Y.-Y., Hu, X.-P., Jin, Z.-Y., Xu, X.-M., \& Chen, H.-Q. (2014). Effect of temperature-cycled retrogradation on in vitro digestibility and structural characteristics of waxy potato starch. International Journal of Biological Macromolecules, 67, 79-84. https://doi.org/10.1016/j. ijbiomac.2014.03.007

Yuwono, S. S. \& Susanto, T. (1998). Pengujian Fisik Pangan. Fakultas Teknologi Pertanian. Universitas Brawijaya. Malang.

Zhang, G., \& Hamaker, B. R. (2009). Slowly digestible starch: concept, mechanism, and proposed extended glycemic index. Critical Reviews in Food Science and Nutrition, 49(10), 852-867. https://doi. org/10.1080/10408390903372466 